\title{
The current Afro-optimism - A realistic image of Africa? ${ }^{1}$
}

Kjell Havnevik

Nordic Africa Institute/University of Agder, Kristiansand

Kjell.Havnevik@nai.uu.se

\section{Keywords:}

Afro-optimism

the Economist

economic development

demographic change

conflict

governance

democratisation

1 I am thankful for comments to earlier versions of this chapter from Mats Hårsmar, Sten Hagberg, Edyala Yglesias, Rune Skarstein, Kristen Nordhaug and an anonymous reviewer. 


\begin{abstract}
This chapter raises the question whether the current Afro-optimism can be considered a construction of a realistic image (situational) and a narrative (process) of Africa. It does so primarily by analyzing the 180 degree turn-around of the prestigious and influential magazine, The Economist, on Africa within the time span of a decade. In May 2000 the magazine claimed that Africa was a continent without hope, whereas in December 2011, Africa, according to The Economist, could be considered a continent of hopeful economies where "the sun shines bright." The chapter identifies and analyses the key editions of The Economist with reference to this complete turn-around on Africa. Three major pillars are identified in the analysis of The Economist in relation to the changes in Africa, (i) the economic pillar (economic growth, investments and trade), (ii) demographic change and (iii) conflict, governance and democratization. Within each pillar a presentation of The Economist's description and analysis is put forward to be followed by critical reflections by the author. The presentations and reflections also have reference to the analysis/empirical studies on Africa by key research institutions.

In the concluding reflections of the chapter, the importance of culture for the understanding of African change - only mentioned in passing by The Economist - is put forward through concrete examples. The findings are that the Afro-optimist images/narrative put forward by The Economist and others do not hold together even if analysed from within its own frame. The analysis of The Economist and the Afro-optimist narrative also shows that it becomes fragile when confronted with an understanding of Africa that integrates cultural perspectives. The Afro-optimist narrative of The Economist has been constructed within a limited knowledge and timeframe that has restricted a deeper understanding of Africa. The conclusion of the chapter is that the way The Economist has constructed its arguments for Africa-optimism has helped create a narrative that aims at legitimising the continued exploitation of Africa.
\end{abstract}




\section{Introduction}

The current Afro-optimism is manifested in many ways through influential and powerful voices. The Economist, one of the world's most prestigious and respected magazines, has through various editions given special relevance to this theme. As we know, this magazine is an important opinion maker that influences the way people and organizations, particularly in Europe and the West, interpret and construct their vision of economic and political matters.

In December 2011, The Economist's headline on Africa turned very optimistic: "Africa's hopeful economies: the sun shines bright." In response to those still doubtful about Africa's improvements, the magazine in March 2013 came back to the subject, publishing a Special Report on Africa (SRA) titled "A hopeful continent." The report forcefully proclaimed: "Yet despite the caveats, the Africa-pessimists have got it wrong. This time the continent really is on the rise" (SRA, 2013, p. 16).

Curiously, only a decade earlier the renowned publication had stated that Africa was "a hopeless continent" (May 13, 2000): floods in Mozambique and Madagascar; famines in Ethiopia and Zimbabwe; wars that spread from north to south, from east to west were the African images presented by the magazine. The Economist's vision of Africa was then circumscribed by its understanding that although despotism, brutality and corruption exist everywhere, "African societies for reasons buried in their cultures, seem especially susceptible to them." Indeed, The Economist had altered its view on Africa 180 degrees by 2011.

It seems that The Economist itself felt a bit uneasy about its dramatic change of opinion on Africa. Was it convincing to come up with diametrically opposite perspectives on a whole continent during a time span of only a decade? Had floods, conflicts, famines and epidemics vanished from the African continent? In an attempt to remove any doubt about the new 'African realities' the magazine sent one of its correspondent's (Oliver August) on a 122 day trip visiting different regions and countries of Africa in order to develop The Economist's March 2013 Special Report on Africa. The two first lines of the report presented in bold letters sum it up, "African lives have already greatly improved over the past decade, says Oliver August. The next ten years will be even better" (SRA, 2013:3).

The Economist's prestige and influence makes it both interesting and important to acquire an understanding of how it constructed its arguments to justify the dramatic change of its editorial line on Africa. Others have also analyzed African change over time and there seems to be a consensus that the 1980 s and 1990 s can be termed "lost decades" as regards growth and developments in Africa (Eriksen, 2012, p. 127). The positive changes that started to emerge in Africa towards the end of the 1990 s had been overlooked by The Economist when it trumpeted its 'hopeless continent' perspective in 2000 . Other agencies, institutions and many researchers indicated cautious optimism about Africa during the first decade of the new millennium (Eriksen 2012, p. 127-129; UNCTAD 2012a; UNECA 2012 and 2013). Only eleven years later, in 2011, The Economist presented its notions about Africa's hopeful economies - the sun shines bright.

The title of this chapter refers to whether the term Afro-optimism - of which The Economist is a dominant voice, is based on realistic images or not. With an image I mean representation and hence my wish was to inquire into whether the imagery presented by The Economist corresponded to changes in Africa in a truthful way? In order to better understand the background for the construction of The Economist's arguments, I analysed various editions of The Economist and in particular the editions from May 2000, December 
2011 and March 2013 which are key editions in terms of the manifestation of The Economist's dramatic change of perception on Africa.

It emerged that The Economist's frame of argumentation with respect to Afro-optimism focuses on three major pillars. The economic pillar is the most dominant and reflects The Economist's understanding of economic change through indicators of growth, trade and investments. A second pillar addresses the challenges of demographic change and the third deals with issues connected to conflict, governance and democratisation.

It is clear from the approach of The Economist that the African culture was not taken into account. A cultural perspective on processes of change would certainly help to provide a more accurate and realistic understanding of African economic, political and institutional complexities. This could be helpful for assessing the realism of the representation that The Economist and other Afro-optimists have produced or generated regarding Africa.

Furthermore, my study of The Economist and other literature made me ask the question whether Afro-optimism was also about presenting images of Africa in a certain way situating them so they contributed to a new narrative on Africa. With narrative I mean the representation of a process in such a way as to reflect or conform to an overarching set of aims or/and values. Although the Afro-optimism narrative was on the rise generally, the dramatic change of perception of The Economist on Africa between 2000 and 2011/13 made me pose the following questions:

-Were The Economist's arguments constructed as part of an inquiry into whether Africa could attain sustainable development which could transform the continent's economy and eradicate its poverty?

-Or, was it connected to the economic stagnation in Europe and the rest of the world and the search by international capital for new territories to invest in natural resources and land?

-Did The Economist wish to construct a new image and narrative of Africa as the 'promised land'?

-For whom and for which reasons was The Economist constructing this new narrative of Africa?

I will reflect critically on these issues in connection with my subsequent presentation of the description and analysis of The Economist's turn-around on Africa.

My motive for engaging with this topic is that I find that the space for critical opinions and analyses about recent changes in Africa is shrinking. In response to this I wish to contribute to the construction of an understanding of Africa which holds sway over time - to a realistic understanding of Africa. In this effort I draw on four decades of research and educational work with focus on Africa, conducted in Norwegian, Tanzanian and Swedish universities and research institutions. Let me now investigate more concretely the Afro-optimistic descriptions and analyses within the new narrative presented by The Economist and with reference to other Afro-optimists. 


\section{The Economist's Afro-optimistic analyses and reflections on economic development}

\section{The Afro optimistic analysis of economic growth}

The main reason for the dramatic change of assessment of Africa by The Economist and Afro-optimists is the continent's recent economic growth. The image of this new growth that has stuck in most reports is that eight to nine of the fastest growing economies of the world are located in Africa. African institutions are more cautious. The UN Economic Commission for Africa, UNECA concluded that, "Yet this impressive growth story has not translated into economic diversification, commensurate jobs or faster social development." UNECA underlines that "African countries must therefore address the reasons why stronger growth and trade have not stimulated economic diversification, job creation and social development" (UNECA, 2013:6).

The Economist (SRA, 2013) also refers to caveats in its conclusions along the lines of UNECA but little emphasis is paid to these warnings, thus the Afro-optimistic flavour of the Economist's analysis stands out strongly.

As to the character of African growth, The Economist (May 2011) stated that one third of the continent's recent growth is due to commodities, however The Economist does not make it clear whether this relates only to the growth in volumes of commodities, or the combined effects of volume and price changes. West and Southern Africa are the major beneficiaries from oil exports, while e.g. Equatorial Guinea and Zambia are beneficiaries from copper. East Africa is seen as special by The Economist since the growth in this region is claimed to be no-resource-based and founded more on telecommunication, the service sector and other economic activities.

According to Mo Ibrahim, a Sudanese mobile-phone mogul, "Everything is growing."(Economist, December 3, 2011) The Economist also emphasizes that African growth showed limited decline during the global financial and economic crises in 2008. The chief economist of the Africa Development Bank states that Africa has shown "great resilience" and "a structural change has taken place" (ibid.). Such pronouncements by authoritative sources convey strong perceptions and images of positive change in Africa.

UNECA's (2013) analysis of the African growth scenario also tilts in a positive direction; although commodity based, the African growth has improved domestic demand connected with urbanization and rising incomes, increasing public expenditure, and increasing harvests in some regions. Also, stronger investment and trading ties with emerging economies and post-conflict recovery in some countries have led to growth.

The Economist argues that commodity growth has become more assured (May 2011), and that a major driver of growth is the application of technology. Firstly, this relates to the impact of the spread of mobile phones. In 2013, 600 million Africans owned a mobile phone and 10 per cent had access to mobile internet services. The phones are also used for banking and financial services and dissemination of information about prices and markets. Kenya is held up as an example of this development (SRA, 2013). Secondly, technology change, according to The Economist, is aiding health care. Malaria and HIV/AIDS are examples of illnesses that have become less extreme since, "many more people are receiving effective treatment." The World Bank found that malaria takes USD 12 billion out of Africa's GDP annually. The spread of better mosquito nets have made death rates fall by 20\% (Economist, December 3, 2011). The Economist also informs that malaria deaths in 
some of the worst-affected countries have declined by 30 per cent and HIV infections by up to 74 per cent over the past decade. Following from some of these health improvements, "life expectancy across Africa has increased by about 10 per cent and child mortality rates in most countries have been falling steeply" (SRA, 2013:3). Another major driver of African growth, according to The Economist, is political stability (see below).

The Economist (SRA, 2013) concludes that the real income per person in Africa over the past decade has increased by more than 30 per cent, whereas in the previous 20 years it shrunk by nearly ten per cent. "Africa is the world's fastest-growing continent just now. Over the next decade its GDP growth is expected to rise by an average of six per cent a year, not least thanks to foreign investments."

\section{Critical reflections on the Afro-optimist economic growth scenario}

Statistics confirm that Africa's economic growth over the last decade has been relatively high and stable. Since year 2000, Africa experienced a commodity boom manifested in continuous high growth rates, although they declined from an average of 5.6 per cent for the period 2002 to 2008 to 2.2 per cent in 2009 but, then, quickly recovered to 4.6 per cent in 2010. The political transitions in North Africa led to declining growth rates in 2011, but it rebounded to 5 per cent in 2012 (UNECA, 2013:6).

McKinsey Global Institute (2012) states that the commodity sector, oil, gas and minerals, accounts for around 40 per cent of Africa's GNP but absorbs less than one per cent of Africa's total work force. This implies that the growth performance of Africa has not led to economic diversification, increases in jobs and more rapid social development. The reliance on commodity production and exports with limited value added and few forward and backward production linkages indicates only limited economic transformation.

This scenario can help explain why African growth has not led to any substantial reduction of poverty levels. Growth of FDI has also led to increasing control and influence over the benefits of African economic growth by external interests. Africa's political and commercial elites and parts of a growing middle class have also benefited disproportionally.

The recent global drive in large-scale agro-investments in Africa searches well-watered land and areas and most often alienate pastoralists and smallholder farmers and provides insufficient or no compensation. The Economist itself refers to dramatic conflicts related to land investment and acquisitions in Ethiopia, but the problem exists across Africa (World Bank, 2011; Matondi et al., 2011; Cotula, 2011; FAO 2013; Havnevik, 2014; Abdallah et al., 2014; Skarstein, 2014). Research also shows that the capture of other peoples' land without legal process is driven by domestic interests, at times through linkages between local strongmen and high level public officials (as in Uganda), and at times the linkages extend to external interests (Mbabazi et al., 2013).

Benefits from African growth are also manifested in illegal capital flight. Kar \& Freitas (2012) has estimated that capital flight from Africa is increasing by 12 per cent annually. Its volume is estimated to be twice the inward flow of development assistance to the continent. Large corporations and individuals with extremely high profits and incomes have shifted their base to Switzerland, Dubai and Singapore where corporate and individual tax levels are very low or non-existing and where banking secrecy still is practiced. In addition, African taxation of profits by large foreign companies is low due to favourable regulations comprising tax rebates and generous possibilities for legal repatriation of profits.

The rise of China, and to a lesser extent India, as major investors and donors with geopolitical interests in Africa could potentially help Africa to take advantage of a more 
multipolar power context. This would, however, require an African strategy that could enhance the continent's political and economic position in relation to the new global power regime. Developments so far show that Africa and its major institution, the African Union, $\mathrm{AU}$, is lacking such a strategy that can enable African people to benefit from the continent's own resources and growth (Dietz et al., 2011).

In my judgment, an African economic growth process that can lead to economic and social transformation should be founded on the widening of the continent's productive sectors and the creation of linkages between them. Continuing growth in ICT, financial services and banking can help remove constraints on information, communication and payments, etc., and hence support economic growth. However, efforts across all productive sectors are required for attaining structural and sustainable change.

Over the last three decades smallholder agriculture, the continent's main economic sector, has seen its production conditions deteriorate. This process is overlooked by international and national state institutions alike. Their recent strategies are not taking into account past lessons since they emphasize modernization of agriculture through foreign direct investments based on mechanization and exports. The outcome may well be economic growth for some years, as indicated by UNECA (2013). African economic growth is estimated to be around 5 per cent for 2014 and 2015. In my assessment it is, however, difficult to see how the narrative of Afro-optimism can be sustained beyond the next decade, since the current growth does not seem to lead to structural change, which can widen the productive base of African economies and benefit the majority of the continent's people.

\section{The Afro-optimistic analysis of trade}

The Economist claims that the trade situation has improved markedly for Africa during the last decade. China has become Africa's biggest trading partner and trade between the countries increased from USD 11 billion to USD 166 billion in the last decade (SRA, 2013). Countries that have increased their trade with Africa also include India, Indonesia and Turkey. The trade regime for Africa is thus shifting away from traditional partners to emerging economies. The trade with the latter increased from 23 per cent in 2000 to 36 per cent in 2009. However, the traditional trading partners, the EU and the USA, still account for the major share of trade. Over the same period Africa's total trade increased from 246 to 673 billion USD.

When comparing with China, "the workshop of the world," The Economist in its lead article, "The world's fastest-growing continent. Aspiring Africa" (SRA, 2013:10) states that Africa, "almost exclusively exports are what grows in fields or is dug out from below the ground" (ibid.). The Economist shows awareness of the limitation of the current trade regime of Africa, "Other gains, such as those from commodities may eventually peter out, though not for a while. Many African countries are still discovering new oilfields and mineral deposits" (SRA, 2013, p. 18). The commodity character of African exports is undeniable and it is also the concern of the UNECA (2013). 


\section{Critical reflections on the Afro-optimistic analysis of trade}

Africa's external trading partners continue to focus on its natural resource commodities. Their orientation to commodities tends to block the diversification of production and exports from Africa. A key challenge for Africa is to establish trade agreements with external partners, Europe, China, India etc., which can support the diversification of African economies, increase employment and strengthen technological development. The Economic Partnership Agreements (EPA) negotiated between the EU and African regional groupings during the last decade did not meet such expectations. EU demanded further liberalisation of Africa and access for European companies to African economic and financial sectors. The benefits of such access were found to far outweigh what was offered in return by EU to Africa. Broader regional or continental African initiatives are required for improving African trading conditions so that external markets for processed African products relating to agriculture, natural resources and manufacturing can be opened and sustained. At the same time Africa must demand selective protection of those economic activities or sectors that can build competence and create technologies that can support economic transformation over time. In spite of the rapid increases in African trade over the last decade, Africa is still marginalised in a historical perspective. In 1950 the share of Sub-Saharan Africa trade in world trade was 5 per cent. Recently this figure had dropped to only 1.8 per cent and to only 0.5 per cent if only manufacturing production is accounted for (Sundaram et al., 2011, pp. 17-19; Eriksen, 2012, p. 129).

\section{The Afro-optimistic analysis of foreign investment}

As foreign direct investments (FDI) flow into Africa, the catch phrase of the Economist is "not yet a flood," indicating measured optimism for the future. The Economist (SRA, 2013) presents trends in FDI, both in volume of investments and their distribution across Africa. The volume of FDI was stagnant during 2002 - 2004, averaging around USD 17 billion a year. Then a rapid increase took place from 2005 to 2008, to about USD 60 billion. Between 2008 and 2010 a decline occurred to nearly USD 40 billion and then a gradual rise ended at USD 46 billion in 2012. The regional distribution of FDI shows that the highest share of FDI went to northern Africa from 2006 to 2010, declined drastically in 2011, due to the Arab Spring. The largest share of FDI has been going to Central Africa. It has remained stable from 2008 onwards. East Africa, which by The Economist in 2011 was referred to a dynamic site of special non-resourced-based growth, has received a stable inflow of FDI of about USD 5 billion annually during the period $2007-2012$.

In 2011 Sub-Saharan Africa attained the same levels of FDI inflows as before the 2008 crisis. The decline in FDI for Africa since 2008 has mainly been related to northern Africa. The major part of FDI, however, went only to few countries, Nigeria, South Africa, Ghana, DRC, Algeria, Morocco, Mozambique and Zambia (all receiving above USD 2 billion each) (Hårsmar, 2013).

Interestingly, conflicts related to foreign investments in land in Africa are only discussed in detail by The Economist in the case if Ethiopia. Documentation of such conflicts and their associated violence exist in many African countries. Focusing on Ethiopia in this context helps the magazine strengthen the image, already established in its optimistic vision of Africa, of the negative features of the socialist as compared to the capitalist development model. 


\section{Critical reflections on the Afro-optimistic analysis of foreign investment}

FDI to Africa are likely to increase in the short run in order to sustain economic growth and consumption on other continents. But the pattern of inward FDI to Africa is changing. Emerging economies are rapidly increasing their investments. They accounted for more than half of the FDI in Sub-Saharan Africa (SSA) in 2010. Of the total level of FDI to SSA in 2010, of about USD 90 billion, natural resources and energy accounted for around 50 per cent and service sectors for around 30 per cent. Inflows into the manufacturing sector are low, which is also indicated by its low contribution to African GNP, i.e. around 10 per cent (Hårsmar, 2013). In terms of its contribution to the Gross National Income, GNI, the share of manufacturing for the whole of Africa declined from 15 per cent in 1990 to 10 per cent in 2008, while for West Africa the decline over the same period was from 13 per cent to only 5 per cent (UNCTAD, 2012b).

Current sectors of investment are likely to remain the most important also in the future, including natural resources, oil and gas, minerals, diamonds and food and energy from agricultural land. Conflicts over large-scale land investments are thus likely to increase. Negative outcomes of the current wave of FDI to Africa were revealed in 2009 by international research institutions (IFPRI and IIED) and the United Nations Special Rapporteur on the Right to Food. They subsequently formulated a set of investment guidelines to prevent large-scale agro-investments that alienate smallholders and destroy the environment. Later a proliferation of voluntary guidelines aiming at responsible investments in agriculture emerged. The last one was concluded under the auspices of the World Forum on Food Security in October 2014. Nearly all of these principles and guidelines, however, are voluntary. They cannot be enforced as there is a lack both of capacity and political will among the home governments of the foreign investors, and limited ethical concerns among the majority of foreign investors (Havnevik, 2014; CFS/FAO, 2014).

\section{The Afro-optimistic analysis of the demographic dividend}

An argument underlying The Economist's reconceptualization is to perceive the changing demographic structure of Africa as an opportunity - or a demographic dividend. Africa's population is estimated to double from one billion today to two billion around 2050. This implies that African population growth will account for 50 per cent of the total global population growth until 2050 .

The demographic dividend is explained as an outcome of the low age of the current African population. The current median age of Africans is 20, compared with 30 in Asia and 40 in Europe. When fertility rates drop, that median will increase as today's young people move into productive ages. The ratio of working people to those of younger and older - the dependency rate - will accordingly rise. The argument of The Economist is that a similar 'population dividend' benefited East Asian economies a generation ago and that it again can be available to Africa (May 2011). The notion of the demographic dividend reappears also in 2013: "The continent must make use of this bulge of labour and the savings it produces, for development. If they squander it, Africans will grow old before they grow rich." (SRA, 2013)

Thus, the point is not lost by The Economist that in order to capture the demographic dividend, the rapidly rising number of people in productive ages in Africa must gain employment, as they did in East Asia. Otherwise, the Afro-optimist perspective will not hold. Unlike Africa, the high level of economic growth in East Asia with a rather young population and a low dependency rate was based on labour-intensive industrialisation, which generated employment for broad sections of the population. In the most successful countries, South 
Korea, Taiwan and China this growth was also based on previous land reforms, which led to an increase in the demand from the agricultural sector that expanded internal markets (Amsden, 1988, 2003). The Economist presents statistics that show improvements in education enrolment along with positive health indicators. Should this not imply that the potential African productive population can contribute more efficiently to production, given that work opportunities are created?

One important aspect of the Afro-optimist scenario relates precisely to future job creation. The Economist (December 3, 2011) claims that the growth of the middle class leads to increasing domestic demand that will generate growth. It refers to 60 million African households with an annual income above USD 3,000 at market exchange rates and that the number of such households is expected to grow to 100 million households by 2015 . This situation, it is claimed, is comparable to the level of India in 2011. The Economist also refers to the existence of great income disparities in Africa. In 2013 it reported that "inequality has fallen in only half of Africa's 55 countries" (SRA, 2013, p.16).

\section{Critical reflections on the Afro-optimistic analysis of the demographic dividend}

The magnitude of the demographic challenge in Africa in the short run is illustrated by McKinsey Global Institute (2012). Its findings show that the current potential workforce in Africa is 380 million people that is expected to grow to 500 million by 2020 - surpassing that of China's workforce. McKinsey has estimated that 180 million Africans will be employed (36 per cent) in 2020. This implies that 320 million Africans will lack formal wage employment at that time. The Economist relates to this scenario in the following way: "A youthful population is a blessing in many ways. But if the extra people cannot find jobs, they may cause unrest and instability. South Africa knows this only too well" (SRA, 2013, p. 16).

Africa's possibility to capture the demographic dividend is also related to the global context. In my assessment, high consumption levels in the North, in emerging economies and among the elites of developing countries will continue to make it difficult to simultaneously address climate change and global poverty. Relatively high prices of natural resources and energy-related commodities will, although with some variation over time, create disincentives for African elites to move in the direction of economic transformation. Although short-term prospects may be good, the long-run perspectives give, in my opinion, little room for Afro-optimism. But even in the short run, the declining growth in transition economies during 2014 and the parallel fall in prices of many raw materials are ominous. However, depending on the resource profile of the African country in question, the lowering of prices of natural resources, such as oil since the last part of 2014, may also create new opportunities for energy, in particular in oil-importing countries.

UNECA's strategy (2013) is for Africa to enhance economic diversification as a means to structural change. However the UNECA cannot explain how the necessary economic, political and social changes can be attained. The same applies to World Bank and MDG strategies for Africa. Optimism and well-intentioned goals are insufficient, including those that rely only on economic considerations about African development (Fischer, 2012). In addition to the modernization of smallholder agriculture, revival of the continent's manufacturing sector is a key to Africa's economic transformation. This challenge clearly occurs in the light of the continuous three decades of decline of the contribution of the sector to GNP growth in Africa (Hårsmar, 2013). 
The rapid growth rate of Africa's productive work force and the limited labour absorption of the current productive regime, make it unlikely that Africa will follow Asia and capture the potentials inherent in its demographic dividend.

\section{Conflict, governance and democratisation}

\section{The Afro-optimistic analysis of conflicts, governance and democratisation}

In the area of conflict, governance and democratisation, The Economist (December 3, 2011) refers to the isolation a generation ago of Apartheid South Africa, the continent's largest economy, while only 7 out of 50 countries held democratic elections. Although Africa is still not peaceful and democratic, it has made huge strides forward, according to The Economist. The "dead hand" of the Soviet Union is gone and countries have given up on Marxism (Ethiopia and Mozambique). Dictators (e.g. Mobutu in DRC) that were propped up by superpowers have fallen. Civil wars (exemplified by Angola) have mostly ended (The Economist, May 2011). The Economist also argues that some of the recent gains, such as the boost from declining political violence, "may be one-off." The number of wars that can be brought to an end is diminishing, though the sense of stability that peace brings will grow in the years to come" (SRA, 2013, p. 16). The Economist refers to major conflicts "as those with more than 1000 deaths a years." Although three such major conflicts continue, "they may be getting close to a peaceful resolution" (SRA, 2013, p. 6).

In 2013 the number of African democracies had increased to 25, although of varying shades and many more countries held "imperfect but worthwhile elections" (22 in 2012). Only four of the 55 countries, Eritrea, Swaziland, Libya and Somalia, lack a multi-party constitution" (SRA, 2013, p. 4). The Economist has observed three other paths through which African countries have struggled to improve their citizens' lives, (i) civil strife has declined dramatically, (ii) more private citizens are engaging in politics both in civil society groups, in aid efforts and as protesters and (iii) Africa's retreat from socialist economic models has generally made people better off (SRA, 2013, p. 4).

It is difficult for the Economist to substantiate this conclusion on socialist models in its analysis of socialist Ethiopia. The country has one of the best economic track records of the last decade on the continent. In order to avoid conflicting argumentation, The Economist has relied on critics who argue that Ethiopia's annual productivity gains in agriculture "are probably not 5-6 per cent, as official statistics suggests, but more like 2-3 per cent, although that is still impressive", while "international experts are suspicious of the GDP growth figures of 11 per cent flaunted by the government. They say that the current growth rate is only half that, around 5-7 per cent - which is still respectable" (SRA, 2013, p. 12). The Economist concludes that Ethiopia needs further liberalisation urgently alongside urbanisation in order to generate new jobs and bring down family sizes. This, according to The Economist, will "require capital, usually foreign capital" (ibid).

In Ethiopia, The Economist's correspondent also wished to inquire whether the country's economic growth had reached the poorest. "In order to find out your correspondent hired mules to trek to a series of remote villages in the central highland." He concluded from the reality check that,

Today villagers are as cut off as ever. The nearest paved road is several days' walk away. However, in the past decade they have started receiving government support for the first time. A small state school now offers eight years of education and nurses provide basic health care. 'A great gift for us,' says an old woman hunched over a 
fire. Yet what the government has given it is now threatening to take away again. Huts may be taken down, officials say, to make room of a national park that will earn income from the tourists (SRA, 2013, p. 12).

To underline the flaws of the socialist model, the Economist gives voice to a person identified as a leading Ethiopian economist, "they (Ethiopia) have to open up fully to foreign investment or they'll hit a wall. The model as it is now is unsustainable" (SRA, 2013, p. 13).

The tone is different in the analysis of countries pursuing a capitalist pathway, such as Kenya. Here The Economist finds that market-led development has made the country leading in the East African community. The surest sign of "success is the emergence of a middle class. A good part of the riches is trickling down to ordinary people in Kenya" (SRA, 2013, p. 14). The latter conclusion does not tally well with the subsequent observation that, "Child and maternal mortality remains stubbornly high."

\section{Critical reflections on the Afro-optimistic analysis of conflicts, governance and democratisation}

The Economist is correct in asserting that many conflicts have come to a halt in Africa during the last decade. While governance and democratisation have improved, however, new conflicts have emerged. The Sahel conflicts have expanded into fully fledged wars involving a number of countries. Separatist movements have been taken over by terrorist groups pursuing diverse motives. Conflicts are re-emerging or continuing as well in some of the northern African countries. In Mali the conflict has given rise to foreign intervention by French military forces with the support from African states and the USA. The recent coup in the Central African Republic is also bringing about unrest and political instability in Central Africa and the conflicts in Eastern Congo remain. In fact there is a push for military action as the Democratic Forces for the Liberation of Rwanda (FDLR) ignored the deadline of January 2, 2015 to disarm. As of January 10, the UN and cooperating regional states were only awaiting the green light from the President of DRC to start action (The East African, January 10, 2015).

In the Eastern and Horn of Africa region the war in South Sudan is leading to dramatic losses of life and has had a strongly negative impact on the country's economy, which contracted by 15 per cent during 2014 due to the war (The East African, January 14, 2015). The war can cost regional states as much as USD 53 billion according to a recent report (ibid.). Unrest in Somalia is also continuing. Continuous deaths are occurring in the battles between the UN backed Africa Union Force and fighting Islamists stated to belong to the Somalia's Al-Qaeda affiliated Al Shabaab (The East African, January 15, 2015). The Islamist conflict is also playing out in northeast Nigeria and north Cameroon where Boko Haram have been killing people indiscriminately over some time. This is now threatening to result in serious political implications. The International Crisis Group has warned that tensions within and between major political parties, competing claims to the presidency in Nigeria (elections in February 2015) and the Boko Haram insurgency "are likely to steer the county towards a volatile and vicious electoral contest" (Africa Research Institute, 2015).

The positive call of many Africa optimists regarding the decline in African conflicts or conflict levels can thus to some extent be contested. A number of conflicts have, as indicated above, also had a direct and indirect impact on the economy of many countries. Negative economic impacts are reported to be dramatic in connection with the Ebola epidemic in Guinea, Liberia and Sierra Leone - which is still ongoing (see also below). 
Democratisation is spreading but the process is weak in many countries and susceptible to manipulation by powerful interests. What is required is what can be termed a process in direction of substantial democracy, which is durable and legitimated, not least by making it possible for citizens to assume responsibility for their own country (Bangura 1992; Rudebeck 2013). In order to strengthen the democratic process, many African countries have initiated decentralisation policies, which aim at shifting decision power to lower public administrative levels. However, such devolution of decision power has not been supported by funding. This has blocked the potential for real devolution where lower government administrative levels have greater influence.

During the last decades traditional top-down governance by African states was to some extent substituted by horizontal cooperation between public, private and non-governmental organizations. This opened some space for communities and private citizens in Africa to engage with politics. This development was also observed by The Economist as a positive development (SRA, 2013, p. 4).

In spite of increasing spaces for societal dialogue, violence is however commonplace. This is particular the case in urban areas where many people survive on meagre informal incomes in a context of weakening social norms. Hopes were high among the majority of Africans that the political reforms of the 1990s would bring about economic improvements. When this did not come about, frustrations grew and protests, riots and political instability occurred in many countries.

One area in which Africa has seen steady improvements in terms of accountability is that of macro-economic management. However, more stringent conditions for loans and development assistance by international financial institutions and donors have also caused African states to shrink and limited their capacity to plan for the restructuring of their economies and societies.

\section{Concluding reflections and the issue of culture}

The Afro-optimistic narrative presented by The Economist is framed by three major pillars. The choice of these pillars mirrors the way Europe and the West understand development. The same frame is used for understanding other territories and continents with different histories, cultures and societal contexts. The objective of this chapter has been to critically analyse and reflect on how The Economist constructed its arguments to justify its dramatic change of opinion about Africa.

As to economic analysis, The Economist argues that African economic growth has taken off although it is primarily based on extraction and exports of natural resources, energy and agricultural products. It recommends increases in economic liberalization and foreign direct investments to Africa. This way of framing sustainability emerges clearly in The Economist's discussion of the failure of the socialist model, i.e. Ethiopia, and the success of capitalist models as promoted in Kenya. This latter success is strongly linked to dynamics unfolding in the ITC and the service sectors which are considered important to the rise of the market economy. The fact that the Kenyan model has failed to reduce poverty and inequality is not given any consideration. This is a repetition of the faulty logic of the 1960s - that economic growth would trickle down and take care of poverty reduction (Rostow, 1960). The assumption that economic growth leads to poverty reduction has also more recently been questioned on empirical grounds. A study by the International Poverty Centre for Inclusive Growth focused on economic growth in 80 countries during 1984 - 2001. It showed that only 23 per cent of the growth spells ( 237 growth spells were studied) were found to be pro-poor, 45 per cent did not result in per capita consumption growth and 32 per cent were outright cases of anti-poor growth (Hårsmar, 2014; Son \& Kakwani, 2006). 
The Afro-optimists sees promises in the increase in African trade with the external world. The pattern of trade is changing in direction of new partners, in particular China and India, whereas the traditional trading partners in Europe and the US remain. The composition of foreign direct investors is changing in the same direction as that of trade partners. This may open opportunities for Africa in breaking the shrinkage of the development space and the space for self-determination which resulted from the era when the US and UK dominated trade agreements. According to Robert Wade, the US, UK and their allies were driving a proliferation "of international market-opening and technology-rent-protecting regulations, using multilateral economic organizations, international treaties and bilateral agreements. At the same time the US and the EU did not follow through on their general commitments to improve market access in their own countries for developing countries." (Wade, 2003)

My main criticism of the Afro-optimistic narrative as regards the economic pillar is its flawed conceptualization of sustainability. I especially criticize the inability of the Afro-optimistic narrative to explain how Africa can shift in the direction of poverty reduction and economic transformation. The shift from the pro-poor growth concept to that of inclusive growth by major international institutions such as the OECD and the World Bank is in my opinion a shift in the wrong direction (OECD, 2006; Ianchovichina \& Lundstrom, 2009). Inclusive growth is not concerned with inequalities and focusses more generally on the opportunities for the majority of the labour force, poor and middle-class alike. The concept of inclusive growth could be seen to undermine the OECD/DAC Guidelines for Poverty Reduction (OECD, 2001; Eyben, 2014). In this regard, The Economic Commission for Africa (2012, p. 66) has a better approach in stating that piecemeal changes will be insufficient - only a fundamental break with the current resource and export based growth model that has been recommended to Africa will be sufficient (Eriksen, 2012, p. 129).

The current drive in the direction of large-scale land investments in Africa is supported by the Afro-optimist narrative. This is mainly investment in mechanized production that requires land but little labour. Such strategies have been pursued by other countries, e.g. Brazil, resulting in rapid urbanization and high levels of inequality and crime, changes in land use regimes with the spread of monoculture, which erodes biological diversity and impacts negatively on the climate (Nobre, 2013).

The increase in large-scale investments in land and water in Africa, primarily for export, will lead to the further alienation of smallholders from their land, with limited compensation in terms of wage labour. Brazilian statistics show that large-scale agriculture requires two workers to manage 100 ha while smallholder agriculture requires fifteen smallholders (Fernandes et al., 2012). Smallholder agriculture also allows for more diverse cultivation, which can address environmental and climatic issues in a constructive manner. My judgement is that modernisation of African rural and agricultural development, including food production, should primarily focus on improving production conditions and market access of smallholders (see also Coulson, 2013; van der Ploeg, 2014; Havnevik, 2014).

In support of sustainable development Africa needs to negotiate trade agreements with external trading partners that can support reasonable access to external markets for raw materials as well as processed products with the potential to retain added value in Africa. Educational reform and technological development are important aspects of the enhancement of more diversified economic basis for Africa which also integrates productive processes that can add value.

The Economist's conceptualization of sustainability further relies on increased external investments for Africa to develop. This clearly emerges in The Economist's April 2013 edition in an article titled, "Investing in Africa - the hottest frontier," which offers investment advice to its readers; 
"Investors in Africa are buying a big-picture story of progress towards a formal and regulated economy with stable politics, the rule of law and independent central banks and stricter accounting principles. That prospect is brighter than it was. Nobody can guarantee that future progress will be in a straight line. But given the troubles in large parts of the rich world, many will feel there is a lot more to gain than to lose." (April 2013)

Hence it emerges that a main driving force for The Economist in the construction of its Afrooptimism narrative was to convince foreign investors that Africa had matured to become a 'safe terrain' for investments in natural resources, energy and land.

The Afro-optimist narrative does not, in my judgment, take seriously the issue of how the tremendous increase in Africa's productive labour force can be employed. The strategies recommended are primarily linked to the critical role of increases in foreign direct investments without concern for employment generation. This in my judgment is irresponsible. The conceptualization of sustainability by The Economist, where the growing number of Africans in the working age is envisaged a demographic dividend, has no support in assessments of Africa that aim to be realistic. The question of a demographic dividend must be related to the promotion of a more labour-intensive development model that is connected to efforts to improve the education system, not just in terms of enrolment, but also in terms of how students learn, what they learn and the objectives of learning (Freire, 1970). Such an educational reform will also play an important part in the formation and strengthening of African youth to identify problems and solutions that could be beneficial their own continent.

Afro-optimists, including The Economist, show that reduction of conflicts, spread of democratization and improvements in governance have occurred in some areas. As shown above, this can be contested when the recent rise of conflicts in Africa is taken into account. Overall, however, the space for civil society in Africa has widened. The challenge is for African civil society organisations and movements to grow so powerful that they can make effective demands on their governments to respond to the needs of the citizens. This will imply a deepening of previous processes of formal democratisation to include the mobilisation of rural people. However, in many areas and countries of Africa, civil society activities are dominated by international non-governmental organisations that give priority to charity over justice. This limits their potential contribution to the creation of sustainable societies in Africa.

The Afro-optimist narrative does not hold even if analysed from within its own frame. The Economist's vision of cultural characteristics of Africa was limited to Africa being especially susceptible to despotism, brutality and corruption "for reasons buried in their cultures". But are such features outside of culture - are they not part of it? Anyway, why are African cultures more susceptible than others to such features? The Economist provides no historical analysis to help the reader understand these features of African culture. The Economist's Afro-optimism narrative gives no space to culture, except for punctual comments.

In fact, the Afro-optimist narrative becomes fragile when confronted with an understanding of Africa that integrates cultural perspectives. For instance, in 2014, only one year after The Economist had presented its Afro-optimism narrative, the Ebola epidemic broke in West Africa. Thousands have died and thousands are contaminated - the epidemic is continuing to spread at end of 2014. In this epidemic the role of modern technology, seen as one of the major drivers of African economic growth by The Economist, was put to a test in aiding 
health care. But Ebola proved that the West African governments where Ebola hit had no modern technological capacity to deal with the epidemic.

One important reason for the rapid and continuing spread of the Ebola is that the dead according to culture and rites shall be cleaned and washed before burial. This creates a strong cultural source for the spread of the epidemic. No instruction or information can change such deep-seated cultural features in the short run. The case of Ebola shows that African culture does not work according to functionalist and rational frames used by The Economist to understand African change.

Culture is also guiding African land ownership and use. Over centuries customary land ownership systems have been based on reciprocity and redistribution securing the livelihood of the clan or the tribe (Amanor, 2011). Culturally the meaning of land is complex, relating to belonging, ancestors, food and survival. African rural people have for a long time been stewards of the land, taking care of it for delivery to the next generations. This makes it difficult for rural people to comprehend the notion of private ownership to land, which gives exclusive rights and rights to sales of land. The transition to private ownership in land connected with foreign direct investments in Africa therefore faces very difficult situations when the transfer of land from smallholders to external investors is required. In this setting evolving conflicts put at risk both the livelihood of rural people and the investment itself (FAO, 2013, Havnevik, 2014). To prepare the ground for investments without conflicts, there has to be an understanding of African land tenures and their cultural foundations.

The Afro-optimist narrative has been constructed within a limited knowledge and time frame that has undermined the conditions for a deeper understanding of African change. Such narratives can work as explanations and inspirations for a while. But in order to construct an understanding of Africa that can hold its quality over time, the complexity of African societies and cultures has to be integrated in the analysis. This also means that Africa has to be understood more on its own term. This is also important for the outlining of strategies and policies that can support African economic restructuring and poverty reduction. The Afro-optimistic narrative as presented by The Economist does not aspire to construct such knowledge. Rather The Economist in its construction of the arguments for optimism helped create a narrative, which is aiming to legitimise the continued exploitation of the continent. 


\section{References}

Abdallah, J., L. Engström, K. Havnevik and L. Salomonsson (2014). Large-scale land acquisitions in Tanzania: A critical analysis of practices and dynamics. In Kaag, M. \& Zoomers, A. (Eds.). The Global Land Grab - Beyond the Hype. London/New York: Zed Books.

Africa Research Institute (2015). Elections in Africa. Accessed January 15, 2015 at http://www.africaresearchinstitute.org/blog/2015-elections-africa/

Amanor, K. (2011). Land Governance in Africa. How Historical context has shaped key contemporary issues relating to policy on land (Framing the Debate Series, no. 1). Rome: International Land Coalition.

Amsden, A. H. (1988). Asia's Next Giant: South Korea and Late Industrialisation. Oxford: Oxford University Press.

Amsden, A. H. (2003). The Rise of "The Rest" - Challenges to the West from Late Industrialising Economies. Oxford: Oxford University Press.

Bangura, Y. (1992). Authoritarian Rule and Democracy in Africa: a Theoretical Discourse. In L. Rudebeck (Ed.). When Democracy Makes Sense. Studies in the Democratic Potential of Third World Popular Movements (pp. 69-104). Uppsala: AKUT, Uppsala University.

CFS/FAO, Committee for World Food Security and the Food and Agricultural Organisation of UN (2014). Principles for Responsible Investments in Agriculture and Food Systems. International Agreement on Responsible Investments in Agriculture and Food Systems. Rome: FAO.

Coulson, A. (2013). The end of the peasantry? Reflections based on Henry Bernstein's Class Dynamics and Agrarian Change. Mimeo.

Cotula, L. (2011). Land Deals in Africa: What is in the contracts? London: IIED.

Dietz, T., Havnevik, K, Kaag M. \& Oestigaard, T. (Eds.). (2011). African Engagements Africa negotiating a multi-polar world. Leiden: Brill Publishers.

http://dx.doi.org/10.1163/ej.9789004209886.i-390.5

The East African

(2015, January 10$)$

(2015, January 14$)$

(2015, January 15$)$

The Economist

(2000, May 13). Hopeless Africa, p. 17.

(2011, Dec. 3). Africa's hopeful economies: The sun shines bright, pp. 82-84.

(2013, April 6). The hottest frontier: Investing in Africa, pp. 81-83.

(2013, March 2) Special Report on Africa (SRA).

Eriksen, Tore Linné (2012). Fattig og rik i samme verden. Oslo: FN-Sambandet. http://www.rorg.no/Ressursguider/Fattigdom_og_ulikhet/index.html

Eyben, R. (2014). Debating Empowerment: A case study of knowledge practices in the Development Assistance Committee. Mimeo.

FAO, Food and Agricultural Organisation of the United Nation (2013). Trends and Impacts of Foreign Investments in Developing Country Agriculture. Evidence from case studies. Rome: FAO. 
Fernandes, B. M., Welch, C. A. \& Goncalves, E. C. (2012). Land Governance in Brazil. A geo-historical review of land governance in Brazil (Framing the Debate Series no. 2). Rome: International Land Coalition.

Fischer, A. F. (2012). Inequality and the universalistic principle in the post-2015 development agenda. The Hague: Institute of Social Studies.

Freire, P. (1970). Pedagogy of the Oppressed. New York: Continum.

Havnevik, K. (2014). Responsible agricultural investments in developing countries - how to make principles and guidelines effective (Swedish FAO Committee, Publication Series no. 9). Stockholm: Ministry of Rural Affairs and the Swedish FAO Committee.

Hårsmar, M. (2013, April). Our Afro-Optimism - true image of Africa? Paper presented at The Nordic Africa Institute, Uppsala.

Hårsmar. M. (2014). Misconceptions and poor understanding. Mimeo.

Ianchovichina, E. \& Lundström S. (2009). Inclusive growth analytics: Framework and application (World Bank Policy Research Working Paper no. 481). Washington D.C.: World Bank Group. http://dx.doi.org/10.1596/1813-9450-4851

Kar, D. \& Freitas, S. (2012). Illicit Financial Flows from developing countries: 2001 - 2010. Washington D.C.: Global Financial Integrity.

Matondi, P., Havnevik K. \& Beyene A. (Eds.) (2011). Biofuels, Land Grabbing and Food Security Africa. London/New York: Zed Books.

Mbabazi, P., Muriisa R. \& Twinamatsiko, M. (2013, April). The Invisible Hand in Land Grabbing in Uganda and Rural Development. Paper presented at the Nordic Africa Institute, Uppsala.

McKinsey Global Institute (2012). Africa at work: Job creation and inclusive growth in Africa. Washington: McKinsey Global Institute.

Nobre, C. (2013, October 28). GHG emissions from Brazilian Amazon deforestation: an historical overview of emissions and policies. Paper presented at conference on Deforestation and REDD+ in Brazil. What is going on?, Oslo.

OECD (Organisation for Economic Cooperation and Development) (2001). The DAC Guidelines for Poverty Reduction. OECD, Paris.

OECD (Organisation for Economic Cooperation and Development) (2006). Promoting ProPoor Growth: Key policy messages. OECD, Paris.

Rostow, W. W. (1960). The Stages of Economic Growth: A Non-Communist Manifesto. Cambridge: Cambridge University Press.

Rudebeck, L. (2013, October). Democracy and Sustainable Development. Paper presented at conference on The Intersection of Society and Nature in Sustainability Research, Uppsala University.

Skarstein, R. (2014). Primitive accumulation: concept, similarities and varieties. Mimeo.

Son, H. \& Kakwani, N. (2006). Global estimates of pro-poor growth (IPC Working Paper no. 31). Rio de Janeiro: International Policy Centre for Inclusive Growth.

SRA (2013). Se The Economist (2013, March 2) Special Report on Africa.

Sundaram, J.K. et al. (2011). Globalization and development in sub-Saharan Africa (DESA Working Paper no. 192). New York: United Nations, Department of Economic and Social Affairs.

UNCTAD, United Nations Conference on Trade and Development (2012a). UNCTAD Trade and Development Report, 1981-2011. Three decades of development thinking. New York: UNCTAD. 
UNCTAD, United Nations Conference on Trade and Development (2012b). Economic development in Africa report. Structural transformation and sustainable development in Africa. New York: UNCTAD.

UNECA, United Nations Economic Commission for Africa (2012). Economic report on Africa 2012. Unleashing Africa's potential as a pole of global growth. Addis Ababa: UNECA.

UNECA, United Nations Economic Commission for Africa (2013). Economic report on Africa 2013. Making the Most of Africa's Commodities: Industrializing for Growth, Jobs and Economic Transformation. Addis Ababa: UNECA.

van der Ploeg, J. D. (2014). Peasant driven agricultural growth and food sovereignty. The Journal of Peasant Studies, (41)6, 999-1030.

http://dx.doi.org/10.1080/03066150.2013.876997

Wade, R. (2003). What strategies are viable for developing countries today? The World Trade Organization and the shrinking of 'development space'. Review of International Political Economy, (10)4, 621-644.

http://dx.doi.org/10.1080/09692290310001601902

World Bank (2011). Rising Global Interest in Farmland: Can it yield sustainable and equitable benefits? Washington D. C.: World Bank Group. 